\title{
Molecular identification of Corynebacterium pseudotuberculosis in sheep
}

\author{
Ugur Parin ${ }^{1}$, Sukru Kirkan ${ }^{1}$, Kerem Ural'2, Serap Savasan¹, Goksel Erbas ${ }^{1}$, \\ Mehmet Gultekin ${ }^{2}$, HafizeTugba Yuksel ${ }^{1}$, Canberk Balikci ${ }^{2}$ \\ University of Adnan Menderes, Faculty of Veterinary Medicine, ${ }^{1}$ Department of Microbiology, \\ ${ }^{2}$ Department of Internal Medicine, Isikli, Aydin, Turkey \\ Received July 7, 2017 \\ Accepted April 3, 2018
}

\begin{abstract}
Caseous lymphadenitis is still a serious zoonotic problem in Turkey. Sheep suffer from the disease with yield loss in wool and meat production. Moreover, with inexperienced laboratory staff, biochemical identification may go unrevealed. The scope of this study was to demonstrate the presence of Corynebacterium pseudotuberculosis in sheep by PCR. The sampling was conducted via collecting lymph fluids from the lymph node internal pouch wall of 100 sheep that were examined for the presence of Corynebacterium pseudotuberculosis. Molecular identification of the Corynebacterium pseudotuberculosis isolates was carried out by establishing the presence of the proline iminopeptidase gene. All isolates were confirmed to be Corynebacterium pseudotuberculosis by polymerase chain reaction. The polymerase chain reaction procedure conducted in this research was observed to be reliable and fast, and could be utilized for confirmation of caseous lymphadenitis in sheep as an optional technique to timeconsuming biochemical identification methods.
\end{abstract}

\section{Pleomorphic bacteria, caseous lymphadenitis, proline iminopeptidase, PCR}

Caseous lymphadenitis (CL) is a bacterial disease that causes considerable economic loss in sheep and goat industries (loss of skin and carcass value, loss of weight, loss of reproductive activity, and reduced milk yield) in many countries around the world (Guimaraes et al. 2011). Corynebacterium pseudotuberculosis (C. pseudotuberculosis) is a gram-positive, facultative intracellular actinomycete that causes chronic bacterial disease in sheep, goats, and other warm-blooded animals with caseous lymphadenitis (CLA) (Dorella et al. 2006). Pleomorphism in fresh C. pseudotuberculosis cultures is like that of Corynebacterium diphtheriae, and other bacterial species, in terms of microscopic morphology. However, metachromatic granules are better detected using the staining methods of Neisser and Albert (Ilhan 2001). Colonies are easily broken down and dispersed on agar, but are less dispersed in liquid medium (Paracikoglu and Aydin 2006). Laboratory diagnosis is usually achieved through confirmation using bacterial cultures and by biochemical, serological and nucleic acid-based detection methods (Baird and Fontaine 2007; Guimaraes et al. 2011).

The microorganism continues to multiply in host cells after being taken up by macrophages, which are disrupted and the microorganism is released thereafter. Released microorganisms are subsequently taken up by other circulating phagocytic cells and the cycle is repeated. This repeated phagocytosis cycle has been reported to cause recurrent lesions in C. pseudotuberculosis infections in sheep (Yeruham et al. 1997).

In this study, the presence of $C$. pseudotuberculosis was identified in suspected cases of caseous lymphadenitis in sheep, using bacteriological cultures and polymerase chain reaction (PCR), in the Aydin Province of Turkey.

Address for correspondence:

Dr.Ugur Parin

Department of Microbiology

Faculty of Veterinary Medicine

University of Adnan Menderes, 09016 Turkey 
Materials and Methods

Sampling

Abscess materials were collected from the parotid, retropharyngeal, submandibular, prescapular, popliteal, and prefemoral lymph nodules of 57 female and 43 male Sakiz sheep with enlargement and abscesses in clinically examined superficial lymph nodes (Plate I, Fig. 1). All sheep were from the Aydin Province of Turkey, bred for wool production in semi-open free stall sheep barns, and were suspected of having caseous lymphadenitis. Samples were collected from animals by clearing the lymph node with $70 \%$ ethanol followed by incision of the pouch, which was excised from the lesion using a sterile swab once the lymph fluid had been aspirated with a sterile syringe. All samples were collected from the inner membrane of the excised pouch and transported under the cold chain to the Department of Microbiology and Laboratory Diagnostics.

The Local Ethics Committee of the Adnan Menderes University, Turkey approved ethical clearance for this study (Document No: 09.10.2014, 64583101/2014/169) which was conducted in compliance with animal welfare.

\section{Bacteriological culture examination}

Pouch swab specimens were inoculated directly on blood agar containing $5 \%$ defibrinated sheep blood. White, opaque, haemolytic, and convex colonies that formed after incubation at $37{ }^{\circ} \mathrm{C}$ for $72 \mathrm{~h}$ were investigated for the presence of $C$. pseudotuberculosis (Quinn et al. 2011). Following macroscopic examination of the bacterial colonies, Gram staining was conducted and suspected colonies of C. pseudotuberculosis were inoculated on cystine tellurite blood agar (cystine tellurite agar; $5 \%$ sheep blood supplemented with $1 \%$ potassium tellurite) and incubated at $37^{\circ} \mathrm{C}$ for $72 \mathrm{~h}$. Following incubation, black colonies were evaluated for haemolysis, $\mathrm{H}_{2} \mathrm{~S}$ production, urease reaction, DNase, catalase, nitrate reductase, glucose, maltose, sucrose, starch, and pyrazinamidase activity (Guimaraes et al. 2011). The haemolytic bacterial isolates were identified as C. pseudotuberculosis, by the fact that catalase, DNase, $\mathrm{H}_{2} \mathrm{~S}$, urease, nitrate reductase reaction tested as positive, pyrazinamidase reaction negative. The utilization of glucose, maltose and starch were also regarded as a positive reaction for identification of C. pseudotuberculosis. The various stages of the identification procedures were confirmed using a C. pseudotuberculosis $\mathrm{ATCC}^{\circledR} 43924$ positive control strain.

Genomic deoxyribonucleic acid isolation

The DNA was extracted from pure C. pseudotuberculosis cultures using a bacterial DNA isolation kit (Fermentas ${ }^{\circledR}$, Lithuania), according to the manufacturer's instructions. All isolation steps were conducted in $1.5 \mathrm{ml}$ microcentrifuge tubes.

Polymerase chain reaction

Colonies identified as C. pseudotuberculosis by the biochemical tests were confirmed by PCR. For PCR identification, oligonucleotide primers were designed to target the proline iminopeptidase (PIP) gene, which is the most conserved gene for pathogenic strain determination. The forward primer sequence was 5'-AACTGCGGCTTTCTTTATTC-3', and the reverse 5'-GACAAGTGGGAACGGTATCT-3' (D'A Aonseca et al. 2010). The PCR was prepared using $1 \times$ PCR buffer, $2 \mathrm{mM} \mathrm{MgCl}_{2}, 200 \mu \mathrm{M}$ deoxynucleotide (dNTP) mix, $0.2 \mu \mathrm{M}$ of each primer, $1.25 \mathrm{U}$ Taq DNA polymerase, and $5 \mu$ template DNA at a total volume of $25 \mu 1$ reaction mixture. The PCR conditions were 5 min of pre-denaturation at $94{ }^{\circ} \mathrm{C}$, followed by 35 cycles of $30 \mathrm{~s}$ denaturation at $94{ }^{\circ} \mathrm{C}, 45 \mathrm{~s}$ annealing at $54{ }^{\circ} \mathrm{C}, 45 \mathrm{~s}$ extension at $72{ }^{\circ} \mathrm{C}$, with a final extension step of $5 \mathrm{~min}$ at $72{ }^{\circ} \mathrm{C}$. The amplification reaction mixtures were analysed by $2 \%$ agarose gel electrophoresis and visualized with a gel imaging system. The bands were expected to be 551 bp long (Kumar et al. 2012).

\section{Results}

Corynebacterium pseudotuberculosis was identified from pouch swab samples taken from 100 sheep, by microscopic examination of morphology and analyses of biochemical

Table 1. The isolation number and ratios of Corynebacterium pseudotuberculosis isolates in sheep according to sex.

\begin{tabular}{lcc}
\hline Sex & Isolation number & Isolation ratio (\%) \\
\hline $\begin{array}{l}\text { Female } \\
(\mathrm{n}=57)\end{array}$ & 10 & 17.5 \\
$\begin{array}{l}\text { Male } \\
(\mathrm{n}=43)\end{array}$ & 7 & 16.2 \\
\hline
\end{tabular}
activities at the Microbiology Department of Adnan Menderes University, Faculty of Veterinary Medicine. The colonies were subjected to molecular identification by PIP gene detection (Plate I, Fig. 2).

From these isolation and identification studies, $17(17 \%)$ of the 100 pouch swab samples collected were found to contain 
Table 2. The isolation number and ratios of Corynebacterium pseudotuberculosis isolates in sheep according to age.

\begin{tabular}{lcc}
\hline Age range & Isolation number & Isolation ratio (\%) \\
\hline $0-12$ months & 1 & 6 \\
12-24 months & 3 & 17.5 \\
24-36 months & 10 & 58.5 \\
$36-48$ months & 2 & 12 \\
48 months and older & 1 & 6 \\
\hline
\end{tabular}

Table 3. The regional isolation numbers and ratios of Corynebacterium pseudotuberculosis isolates in sheep according to the lymph nodules.

\begin{tabular}{lcc}
\hline Lymph nodule & Isolation number & $\begin{array}{c}\text { Isolation ratio } \\
(\%)\end{array}$ \\
\hline Parotid & 4 & 23.5 \\
Retropharyngeal & 3 & 17.5 \\
Submandibular & 3 & 17.5 \\
Prescapular & 4 & 23.5 \\
Popliteal & 1 & 6 \\
Prefemoral & 2 & 12 \\
\hline
\end{tabular}

C. pseudotuberculosis. The numbers and ratios of isolations according to sex are presented in Table 1.

The isolation numbers and rates of C. pseudotuberculosis isolates according to age are shown in Table 2.

Regional isolation numbers and ratios according to lymph nodules for C. pseudotuberculosis colonies are shown in Table 3.

In addition to isolation of $C$. pseudotuberculosis, 22 (22\%) Staphylococcus sp., 20 (20\%) Streptococcus sp., 16 (16\%) Bacillus sp., and 13 (13\%) Pasteurella sp. were isolated in this study.

All isolates were examined by PCR and found to be positive for the presence of the PIP gene and thus were confirmed as $C$. pseudotuberculosis.

\section{Discussion}

Caseous lymphadenitis causes important economic losses in somecountries, whereas in others it remains relatively unimportant. The disease is considered a major problem for sheep, and is widespread throughout Europe, Africa, the Middle East, Australia, and the United States. It is suggested there may be a close genotypic relationship between C. pseudotuberculosis isolates of small ruminant origin from different regions of the world, given the disease spread following new migrations and sheep exports to Australia and the United States (Baird and Fontaine 2007). However, disease spread is reported to be lower than disease prevalence in many countries, where it is stated at 8-90\% (Erganis et al 1990; Cetinkaya et al 2002; Al-Gaabary et al. 2009; Guimaraes et al. 2009; Seyffert et al. 2010).

Previous studies have shown that the data obtained for C. pseudotuberculosis prevalence vary. Corynebacterium pseudotuberculosis prevalence was reported to be 4.81\% in a study conducted in Egypt (Mubarak et al. 1999); other studies have reported a prevalence ranging from $0.2 \%$ to $90.07 \%$ (Al-Ga abary et al. 2009, 2010). In addition, bacteriological studies have identified C. pseudotuberculosis at rates ranging from $1.1 \%$ to $32.6 \%(\mathrm{Al}-\mathrm{Gaab}$ ary etal.2010; Hass an etal.2011; Zavoshti etal.2011). Isolation of C. pseudotuberculosis has also been reported as troublesome, depending on the infection stage of the disease, the immune status of the animal, and the presence of other bacterial species in the abscess content (Al-Gaabary et al. 2009). Studies have also shown that caseous lymphadenitis caused by C. pseudotuberculosis has caused loss of yields in Asia, Africa, Central, and South America (Guimaraes et al 2011).

Studies carried out in different regions of Turkey found that caseous lymphadenitis is especially prevalent in lambs (Erganis et al. 1990; Cetinkaya et al. 2002; Ilhan 2013). In addition, the presence of $C$. pseudotuberculosis was diagnosed by Enzyme Linked Immonusorbent Assay (ELISA) and dot-blot ELISA (Ilhan 2001).

Sakmanoglu et al. (2015) identified 72 C. pseudotuberculosis strains by colony 
morphology, microscopic morphology, and biochemical characteristics in 1,176 lymph node cultures. Identified strains were further confirmed by PCR.

The true economic loss in result of CLA in Turkey remains unknown. In many countries including Turkey, the actual prevalence of the disease, the rate of infection, and associated losses have largely been ignored. Owing to the very rapid spread and transmission of the disease, eradication after a flock is infected is incredibly difficult. The first step in combating CLA is to identify infected animals so as to prevent disease transmission to non-infected animals or flocks. Although C. pseudotuberculosis is susceptible to various antibiotics in vitro, it can only be treated with a limited range of antibiotics in vivo (Judson and Songer 1991; Baird 2006). Surgical excision of lymph nodes can be used to curb the disease, but this procedure is troublesome, costly, and difficult to implement (Baird 2006).

No difference was found between male and female sheep in terms of susceptibility to the infection; however, there is an important relationship between the prevalence of infection and age. The morbidity rate is low in suckling lambs and sheep of up to one year of age. The morbidity rate increases until the average age of 30 months in association with cutaneous wounds. From the age of 30 months, the morbidity rate decreases, likely because of acquired immunity (Lund et al. 1982; Zaitoun and Bayoumi 1994). In accordance with previous data, no significant difference was found in the isolation rates between male and female animals in this study. When the age interval was evaluated, it was determined that animals infected with $C$. pseudotuberculosis isolates ranged between 24-36 months of age $(58.5 \%)$.

When superficial lymph nodes were considered in this study, it was seen that the isolation rate was the highest among the parotid, prescapular, and submandibular lymph nodes. This scenario was defined as the formation of open wounds due to the anatomically more sensitive cervical and scapular regions during the fracture and penetration of these wounds into the regional lymph nodes. It was also established that bacteria could reach the cervical and scapular lymph nodules regionally through oral administration of water and feed materials contaminated with C. pseudotuberculosis. Fontaine and Baird (2008) utilised immunohistochemical detection methods to detect scattered bacterial clusters in immature fibrosis lesions in the area between the coagulative necrosis region and the capsule. As a similar finding, it is considered that the pouch samples collected in this study contain dead or degenerated bacteria rather than active bacteria, as the isolation rates are lower in this study compared to others.

The PCR is a reliable technique that is frequently used for the direct examination of various clinical and post mortem samples. However, PCR has not been widely used for the direct detection of $C$. pseudotuberculosis in clinical specimens (Pacheco et al. 2007). Methods for pathogen detection have been proposed, which include many of PCR-based methods (Hoorfar et al. 2004) that detect conserved genes specific to pathogenic strains. Numerous bacterial toxins, virulence factors, and information about the genome of the organism have led to an increased understanding of bacterial pathogenicity mechanisms. Since virulence factors are directly involved in mechanisms of bacterial pathogenicity, genes encoding these factors represent ideal targets for the molecular detection of the correct pathology of a relevant bacterial pathogen using different medical methods.

Loci encoding the numerous virulence genes in the pathogenicity islets (PAIs) of the bacterial genome characterize the bacterial life cycle. In the C. pseudotuberculosis genome, there are PAIs containing PIP genes. Therefore, the clinical specimens isolated from the CLA cases found for this study were first confirmed to contain $C$. pseudotuberculosis by bacterial culture and biochemical identification, and then subsequently by PCR. The procedure for detecting the PIP gene for species-based genotypic identification of $C$. pseudotuberculosis was demonstrated to be of diagnostic value. All C. pseudotuberculosis isolates identified in this study were also tested positive by the PIP gene-based PCR, and all PIP positive isolates were identified as C. pseudotuberculosis. 
In conclusion, the incidence of caseous lymphadenitis infection was found to be $17 \%$ in sheep in the Aydin Province in Turkey. In this study, the presence of C. pseudotuberculosis was confirmed by both phenotypic and genotypic methods. It was also shown that the PIP gene used for PCR detection was useful and accurat ein validating isolates identified using their biochemical properties. Through these findings, it was concluded that biosecurity measures against caseous lymphadenitis disease should be taken in and around the Aydin Province in Turkey where sheep breeding is common.

\section{Acknowledgements}

This research was funded by the Adnan Menderes University Scientific Research Committee with the code VTF-15043.

\section{Declaration of Interest}

The authors hereby declare there is no conflict of interest which affects the outcome of this paper.

\section{References}

Al-Gaabary MH, Osman SA, Oreiby AF 2009: Caseous lymphadenitis in sheep and goats: Clinical, epidemiological and preventive studies. Small Rum Res 87:116-121

Al-Gaabary MH, Osman SA, Ahmed MS, Oreiby AF 2010: Abattoir survey on caseous lymphadenitis in sheep and goats in Tanta, Egypt. Small Rum Res 94: 117-124

Baird GJ, Fontaine MC 2007: Corynebacterium pseudotuberculosis and its role in ovine caseous lymphadenitis. J Comp Path 137: 179-210

Baird GJ 2006: Treatment of ovine caseous lymphadenitis. Vet Rec 159: 500

Cetinkaya B, Karahan M, Atil E, Kalin R, DeBaere T, Vaneechoutte M 2002: Identification of Corynebacterium pseudotuberculosis isolated from sheep and goats by PCR. Vet Microbiol 88: 75-83

D’Afonseca V, Prosdocimi F, Dorella FA, Pacheco LGC, Moraes PM 2010: Survey of genome organization and gene content of Corynebacterium pseudotuberculosis. Microbiol Res 165: 312-320

Dorella FA, Pacheco LGC, Oliveira SC, Miyoshi A, Azevedo A 2006: Corynebacterium pseudotuberculosis: microbiology, biochemical properties, pathogenesis and molecular studies of virulence. Vet Res 37: 201-218

Erganis O, Kaya O, Ates M, Istanbulluoglu E 1990: Microbiological and serological investigations on abscessed lymph nodules in sheep slaughtered in Konya EBK combination. Veterinarium 1: 8-11

Fontaine MC, Baird GJ 2008: Caseous lymphadenitis. Small Rum Res 76: 42-48

Guimaraes AS, Carmo FB, Pauletti RB, Seyffert N, Ribeiro D 2011: Caseous lymphadenitis: epidemiology, diagnosis, and control. The IIOAB J2: 33-43

Guimaraes AS, Seyffert N, Bastos BL, Portela RWD, Meyer R 2009: Caseous lymphadenitis in sheep flocks of the state of Minas Gerais, Brazil: Prevalence and management surveys. Small Rum Res 87: 86-91

Hassan NA, Al-Humiany AA, Bahobail AS, Mansour AMA 2011: Bacteriological and pathological studies on caseous lymphadenitis in sheep in Saudi Arabia. Int J Microbiol Res 2: 28-37

Hoorfar J, Malorny B, Abdulmawjood A, Cook N, Wagner M, Fach P 2004: Practical considerations in design of internal amplification controls for diagnostic PCR assays. J Clin Microbiol 42: 1863-1868

Ilhan Z 2001: Detection of Corynebacterium pseudotuberculosis in the sheep by ELISA and dot-blot ELISA. YOK Document Center 108136.

Ilhan Z 2013: Detection of Corynebacterium pseudotuberculosis from sheep lymph nodes by PCR. Revue Med Vet 164: 60-66

Judson R, Songer JG 1991: Corynebacterium pseudotuberculosis: in vitro susceptibility to 39 antimicrobial agents. Vet Microbiol 27: 145-150

Kumar J, Singh F, Tripathi BN, Kumar R, Dixit SK, Sonawane GG 2012: Epidemiological, bacteriological and molecular studies on caseous lymphadenitis in Sirohi goats of Rajasthan, India. Trop Anim Health Prod 44: $1319-1322$

Lund A, Almlid T, Larsen HJ, Steine T 1982: Antibodies to Corynebacterium pseudotuberculosis in adult goats from a naturally infected herd. Acta Vet Scand 23: 473-482

Mubarak M, Bastawrows AF, Abdel-Hafeez MM, Ali MM 1999: Caseous lymphadenitis of sheep and goats in Assiut farms and abattoirs. Assiut Vet Med J 42: 89-112

Pacheco LGC, Pena RR, Castro TLP, Dorella FA, Bahia RC 2007: Multiplex PCR assay for identification of Corynebacterium pseudotuberculosis from pure cultures and for rapid detection of this pathogen in clinical samples. Journal Med Microbiol 56: 480-486 
Paracikoglu J, Aydin N 2006: Corynebacterium infections. In: Aydin N (Ed.): Veterinary Microbiology (Bacterial Diseases). İlke Emek Press, Ankara, Turkey, pp 31-37

Quinn PJ, Markey BK, Leonard FC, Hartigan P, Fanning S, Fitz-Patrick ES 2011: Veterinary Microbiology and Microbial Disease.Wiley-Blackwell,West Sussex, UK, 137 p.

Sakmanoglu A, Hadimli HH, Erganis O, Pinarkara Y, Sayin Z, Kav K 2015: Identification of Corynebacterium pseudotuberculosis strains isolated from sheep and their antibiotic susceptibilities. Eurasian J Vet Sci 31: $116-121$

Seyffert N, Guimaraes AS, Pacheco LGC, Portela RW, Bastos BL 2010: High seroprevalence of caseous lymphadenitis in Brazilian goat herds revealed by Corynebacterium pseudotuberculosis secreted proteinsbased ELISA. Res Vet Sci 88: 50-55

Yeruham I, Elad D, Van-Ham M, Shpigel NY, Perl S 1997: Corynebacterium pseudotuberculosis infection in Israeli cattle: Clinical an epidemiological studies. Vet Rec 140: 423-427

Zaitoun AM, Bayoumi AH 1994: Some epidemiological studies on ovine pseudotuberculosis. Assiut Vet Med J 31: $238-250$

Zavoshti FR, Khoojine AB, Helan JA, Hassanzadeh B, Heydari AA 2011: Frequency of caseous lymphadenitis (CLA) in sheep slaughtered in an abattoir in Tabriz: comparison of bacterial culture and pathological study. Compar Clin Pathol 21: 667-671 
Plate I

Parin U. et al.: Molecular identification ... pp. 3-8

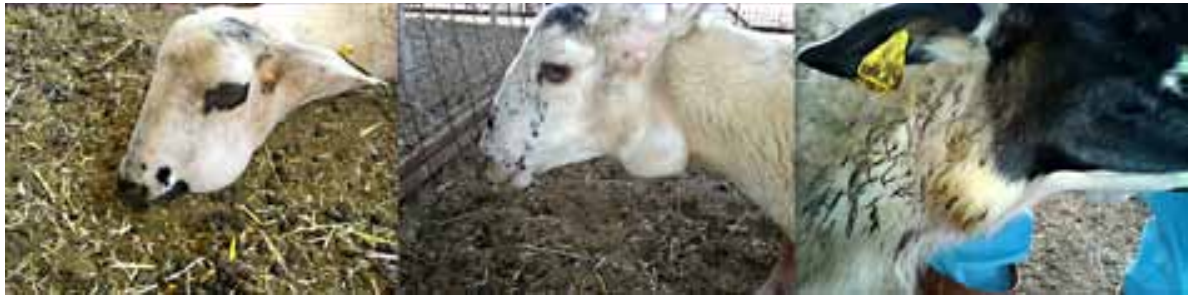

Fig. 1. Examples of three sheep with submandibular, parotid, and retropharyngeal abscesses.

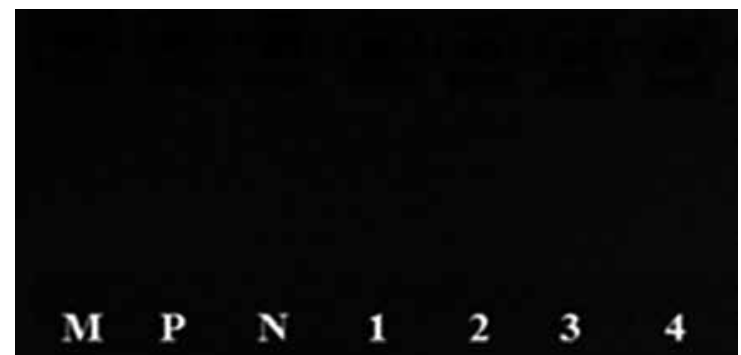

$531 \mathrm{bp}$

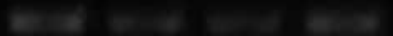

Fig. 2. Results of PCR for C. pseudotuberculosis PIP-specific gene detection. M: 100 bp DNA ladder, P: Positive control (C. pseudotuberculosis ATCC 43924), N: Negative control, 1-4: examples of PIP positive samples.

PCR: polymerase chain reaction; PIP: proline iminopeptidase; DNA: deoxyribonucleic acid; ATCC: American type culture collection 